\title{
The Implementation of SBM in Extracurricular Activities at Elementary School
}

\author{
${ }^{1}$ Prasetyana Nuriyah Fitri \\ Collage Student at Postgraduate UNESA \\ Researchers \\ Surabaya, Indonesia \\ prasetyananf@gmail.com
}

\author{
${ }^{2}$ Sri Setyowati \\ Lecturer of department education management UNESA \\ Lecturer of thesis research education management UNESA \\ Surabaya, Indonesia \\ srisetyowati@unesa.ac.id
}

\begin{abstract}
This study discusses about how the implementation of SBM in support ofextracurricular activities in Airlangga I surabaya Elementary School . SBM itself has three important pillars of participation, transparency and ccountability. The purpose of this study is to see how the implementation of SBM, especially the three pillars are given in extracurricular activities and also how the development of talent interests of students. This research uses qualitative approach with case study method. Data collection by observation, interview and documentation. The result of this study are three pillars of SBM have a positive effect and able to support the extracurricular activities, increasing achievement in academic and non academic activities.
\end{abstract}

Keywords-implementation of SBM, extracurricular

\section{INTRODUCTION}

The main objective of introducing SBM reforms in developing countries is to empower principals and teachers or to strengthening their professional motivation, consequently, enhancing their sense of school belongings. The SBM reforms also have emphasized on parental participations, by means of school boards. [1]

SBM is a management system in which the school is an important decision-making unit on the implementation of education independently. SBM provides greater control opportunities for principals, teachers, students and parents for the education process in their schools.

Even though SBM programs are popular, evidence on the efects of such programs in the country show mixed results. Moreover, there has been no attempt in the literature to explore the underlying mechanisms at work. Posit that SBM can be viewed conceptually as a formal alteration of governance structures, as a form of decentralization that identifies the individual school as the primary unit of improvement and relies on the redistribution of decision making authority as the primary means through which improvement might be stimulated and sustained. Thus in SBM responsibility for and decision making authority over school operations are transferred to principals, teachers, parents and sometimes to students and other school community members. However, these school level actors have to conform to or operate within a set of policies determined by the central government. SBM programs exist in many different forms, both in terms of who has the power to make decisions and in terms of the degree of decision making devolved to the school level. School based management (SBM) is considered as a strategy to decentralize education decision making by boosting parental and community involvement in schools (World Bank, 2007). Bandur (2008) asserted that SBM has become the most prominent feature of the public school management system in most countries around the world. Odden, \& Busch (1998) affirmed that undoubtedly, SBM system is more successful when schools use their decision making authority to recruit and select staff who support and agree with the school's vision. It is clear that SBM system has created opportunities for school administration achieve autonomy, flexibility, participation, and accountability.

Explains that SBM is a form of education reform that redesigns and modifies government structures to schools by empowering schools to improve the quality of national education [2]. Airlangga I surabaya Elementary School is one of the schools implementing SBM. In addition to focusing on academic activities, the school also focuses on non-academic activities such as extracurricular activities. There are three pillars in the implementation of SBM namely participation, transparency and accountability. In Airlangga I surabaya Elementary School these three pillars have been well implemented. In the principal participation stage as the center and also the policy makers in all activities, including the extracurricular in Airlangga I surabaya Elementary School, then the teacher is involved in the implementation of the policy that has been determined by the principal. Students in terms of their participation become the object of the policy.

Effective characteristic of school management focused on four dimensions of environmental, restructuring program, strategic leadership, and school climate. In this case, schoolbased management (SBM) is a new and increasingly popular idea of the decentralization. 
The role of parents in In Airlangga I surabaya Elementary School these three pillars have been well implemented. In the principal participation stage as the center and also the policy makers in all activities, including the extracurricular in Airlangga I surabaya Elementary School, then the teacher is involved in the implementation of the policy that has been determined by the principal. Students in terms of their participation become the object of the policy.In the pillars of participation is to monitor the making and implementation of policies that have been determined by the principal.

Transparency and accountability at Airlangga I surabaya Elementary School in teaching is seen from the teacher's responsibility in preparing, implementing the teaching and evaluating the students especially in the extracurricular activities in the school. There are some other things that must be considered such as discipline, honesty, relationship with students to be important to note so that teachers are able to find out how much improvement in the ability of students during extracurricular activities.

Based on extracurricular activities research is very important in value education because in these activities students get direct experience [3]. Extracurricular activities carried out at school have an important role in improving the quality of students in terms of self-development. Extracurricular activities are not only a means of selfdevelopment but can also be a means of achieving achievement. A variety of extracurricular activities at Airlangga I surabaya Elementary School, including dance (traditional and ballet) bands, scouts, karate, karawitan. But in this discussion, researchers focus only on extracurricular ballet dance, because the extracurricular is more prominent in terms of achievement. Many achievements are inscribed in relation to the extracurricular activities of dance. This dance activity is also performed in a dance studio outside the school.

The big scope of extracurricular activities and their contents enable young people to acquire values and properties which may be of use in their lives. In the era of modern technology, education and research become necessary for being able to do the jobs properly. The human isn't able without knowing things to create, produce and make earning. That's why Ronald Burt deems the generations from 1960s onwards as thinking generations.

School is an educational institution suited to build and strengthen students' character. One of the means to foster students' character building is the implementation of extracurricular activities at schools [4]. Extracurricular activities are defined at activities that student undertake apart from those required to earn a degree [5]. The success of students in extracurricular could be realised through excellent extracurricular management by the teacher and followed with the involvement of students [6]. Extracurricular activities will not succeed if they are not managed properly by the school. Effective management of extracurricular activities can not only support the success of the intra-curricular program, but can support the success of education widely [7]. Management or management activities are activities that cannot be separated from the world of education because it is very influential on the development of the world of education, even education problems that arise in the world of education are also caused by management activities that are not well implemented.Extracurricular activities will not work if not properly managed by the school. Effective management of extracurricular activities not only can support the success of intracurricular programs, but can support the success of education widely. Management or management activities are activities that can not be separated from the world of education because it is very influential on the development of the world of education, even the educational problems that arise in the world of education is also caused by management activities that are not well executed. A balanced mixture in academic and non-academic matters such as extracurricular. By using a good school extracurricular management system Airlangga I surabaya Elementary School can produce students who excel in the field of non-academic.

From that condition, the researcher conducted research on The Implementation of SBM there is an Extracurricular Activities at Airlangga I surabaya Elementary School

\section{METHOD}

a. Research design

This research method used case study research. The research design for case study research comes from 6 sources, namely: documents, archival records, interviews, direct observation, participant observation, and physical devices [8].

b. Research subject

Data sources according to Lofland the main data sources in qualitative research are words and actions and the rest are additional data such as documents and others [9]. The words and behavior of the people observed, interviewed and documented are the main data sources and recorded through written records or through video / audio recording, taking photos or films. Research subjects in this study consisted of principals, school committees, extracurricular coordinators, extracurricular teachers and students who took ballet dance extracurricular activities.

Researchers make research instruments in accordance with the focus of the research, using mobile devices and cameras to record and take pictures of interviews. Each data obtained will be written by the researcher in the form of records of interviews. Data collection methods used in this study are observation, interviews and documentation.

\section{a. Observation}

Explained that researchers in conducting data collection stated frankly to data sources, that he was conducting research [10]. With this observation, it is expected that researchers will get data without any element of confidentiality and obtain data about implementing SBM in extracurricular activities. 
Researchers will observe the implementation of SBM and also extracurricular activities in the Airlangga elementary school.

\section{b. Interview}

Interview is the process of obtaining information for research purposes by means of question and answer, while face to face between the questioner and the answerer by using a tool called the interview guide.

Structured is the method that researchers will use. Explains that with this structured interview each respondent is given the same question and the data collector records it [11].

The aim of the researcher is to use the interview method, to obtain data clearly and concretely about the implementation of SBM in the extracurricular activities of elementary school airlangga. Researchers will ask about the implementation of SBM, student affairs and also the implementation of extracurricular activities in airlangga elementary schools, especially extracurricular ballet dance.

To obtain data from informants, researchers compiled interview guidelines in the form of a list of interview questions that were arranged systematically. This guideline was made before the interview took place so that it could run smoothly and data on the implementation of SBM in extracurricular activities in Airlangga elementary school to be complete because it had been prepared in advance. This interview involved the principal, staff consisting of extracurricular coordinators, psychiatric departments and functional staff consisting of several teaching teachers in the airlangga elementary school.

\section{c. Documentation}

Documentation is a passing event. Documents can be in the form of writing, pictures or monumental works from someone [11]. So it can be concluded that research on the implementation of SBM in extracurricular activities in airlangga elementary schools uses one of the documentation methods, namely data collection by examining important records that are closely related to the object of research.

This documentation data will be used to complete the data obtained from interviews and observations. From this method, the researcher collects everything that the informant has given in the form of photos, activity reports.

\section{d. Analysis data}

After the required data has been collected and considered fulfilling, then the next research activity is to analyze the research data. In principle, Bogdan stated that data analysis can be interpreted as the process of systematically finding and compiling data obtained from interviews, field notes and other materials, so that it can be easily understood and findings can be informed to others [11].

This data analysis is carried out simultaneously and continuously in accordance with the main characteristics of a qualitative research approach that is more concerned with meaning, context and perspective, rather than the breadth of the scope of research.In accordance with the research approach used, the data analysis used is qualitative analysis, including: description, explanation, meaning and interpretation of data. Because qualitative data includes statements, symptoms, nonverbal actions that can be recorded by sentence descriptions or by images.

\section{RESULT AND DISSCUSION}

The big scope of extracurricular activities and their contents enable young people to acquire values and properties which may be of use in their lives. In the era of modern technology, education and research become necessary for being able to do the jobs properly. The human isn't able without knowing things to create, produce and make earning. That's why Ronald Burt deems the generations from 1960s onwards as thinking generations.

Although the provision of extracurricular activities at school has a long tradition in some countries, it was only at the beginning of the millennium that the quality of education and extracurricular activities started to receive increased attention in educational policy and practice [12].

Extracurricular activities are activities that students participate in that do not fall into the realm of normal curriculum of schools. They are found in all levels of our schools. There are many forms of extracurricular activities such as sports, clubs, governance, student newspaper, music, art, and drama [13].

Two groups are expected to be the main beneficiaries of SBM as well as the main guarantors of its successful implementation: the senior teachers, specially the school's principal and the parents, and at times the wider community. In both cases, the transfer of responsibilities will encounter preoccupying challenges.

SBM is a management system in which the school is the unit that produces decisions about self-education. SBM provides an opportunity for principals, teachers, students and parents to process education in their schools. In SBM there are three pillars that support participation, transparency and accountability. SBM and its own three pillars can also support non-academic activities such as extracurricular activities. The existence of some parties that make extracurricular activities, especially in Airlangga I surabaya Elementary School become better and even able to produce international champion. Various parties can also provide that can also improve the quality of extracurricular ballet, in addition to activities in schools, school tuition studio is also available as a means of learning.

b. SBM participation in ballet extracurricular activities At Airlangga I surabaya Elementary School the participation of both the school, community and school committee is very supportive of this extracurricular activity. Many things done by the school committee to help improve the quality of extracurricular activities, when the ballet competition, the school committee in cooperation with the school to invite the community around the school participate in contributing to 
these activities. Forms of participation may include contributions of personnel, funds, infrastructure and technical assistance, among others, the idea of the implementation of extracurricular activities.

c. SBM transparency in ballet extracurricular activities Transparency is necessary to avoid misunderstandings between the school and the school committee as well as the community. In SDN Airlngga I Surabaya the openness between the school and the school committee when explaining the results of the design, implementation and evaluation of extracurricular activities.

d. Accountability of SBM in ballet extracurricular activities In terms of accountability Airlangga I surabaya Elementary School really emphasizes responsibility for all activities including ballet extracurricular activities. Starting from the implementation of the process in which there is planning, implementation and evaluation of activities as well as extracurricular ballet components at Airlangga I surabaya Elementary School .

e. Extracurricular at Airlangga I surabaya Elementary School

Differences before and after the application of SBM in Airlangga I surabaya Elementary School that after applied the SBM with three pillars ekstrakurikulernya increasingly showed the rapid development, especially the extracurricular ballet who get the international champion. That's all thanks to the participation of the school phak itself plus the participation of parents, school committee and the community who participated and contributed.

\section{CONCLUSION}

Based on the results of research that has been described previously, it can be drawn some conclusions as follows.

1. Implementation of SBM and the three pillars in it greatly affect the improvement of school quality, because not only the schools that seek school improvement but also the participation of parents, school committee and the community in improving the quality of schools.
2. With the implementation of SBM in schools can support academic and non academic activities.

\section{REFERENCES}

[1] W. Hutabarat, "Do Organizational Structure And Organizational Culture Affect Teachers'work Motivation To Some Extent," Int. J. Sci. Basic Appl. Res., vol. 20, no. 2, pp. 350-362, 2015.

[2] S. Sagala, Manajemen strategik dalam peningkatan mutu pendidikan. Bandung, 2007.

[3] H. S. Wimalasiri and L. V. K. Jayathilake, "Extracurricular activities and achievements of strategic thinkers in private sector companies in Sri Lanka."

[4] Sardjijo, "Building National Character Through Extracurricular Activity In Smp 'X' Bandung,” 2017.

[5] A. Holland and T. Andre, "Participation in extracurricular activities in secondary school: What is known, what needs to be known?" Rev. Educ. Res., vol. 57, no. 4, pp. 437-466, 1987.

[6] Z. M. Tahira, N. A. Hassana, and N. Othmana, "Performance Measurement for Extracurricular Management at Secondary School Level," Procedia-Social Behav. Sci., vol. 81, pp. 438-442, 2013.

[7] N. Djafri, "Pengaruh kegiatan ekstrakurikuler terhadap prestasi belaja siswa pada pesantren Al-Khaerat Kota Gorontalo," J. Inov., vol. 5, no. 3,2008 .

[8] B. Yazan, "Three approaches to case study methods in education: Yin, Merriam, and Stake,” Qual. Rep., vol. 20, no. 2, pp. 134-152, 2015.

[9] L. J. Moleong, "Metodologi Penelitian Kualitatif edisi revisi," PT Remaja Rosdakarya Offset, Bandung, 2007.

[10] D. R. Sugiyono, Statistika untuk penelitian. 2006.

[11] M. Sugiyono, "Metode Penelitian Kuantitatif, Kualitatif, dan Kombinasi," Bandung Alf., 2012.

[12] N. Fischer, F. Radisch, and M. Schüpbach, "International perspectives on extracurricular activities: Conditions of effects on student development, communities and schools-Editorial," J. Educ. Res. Online/Journal für Bild. Online, vol. 6, no. 3, pp. 5-9, 2014.

[13] S. Annu and M. Sunita, "Extracurricular Activities and Students' Performance in Secondary School of Government and Private Schools," Int. J. Sociol. Anthropol. Res., vol. 1, no. 1, pp. 53-61, 2015. 